\title{
Analysis Resilient Village of Merapi Volcano Eruption in Pusung Village, Boyolali Subdistrict, Boyolali District
}

\section{Mochamad Dendy Arianto}

Universitas Sebelas Maret

muhammaddendy01@gmail.com

Article History

accepted 31/08/2020

approved 22/09/2020

published 28/10/2020

\begin{abstract}
Pusung Village located in the Merapi Volcano Foot. Based on the Kawasan Rawan Bencana (KRB) Map of Merapi Eruption in 2010, Pusung Village was included in KRB I. After the 2010 eruption, Pusung Village began to sister village disaster mitigation program. But in implementation, the disaster mitigation program with all aspects of village resilience to disasters has'nt been optimally. So, this study was conducted to determine the level of toughness Pusung Village and direction the implementation of village resilience. The method is scoring and SWOT analysis of questionnaires and observation. The results of this study are Pusung Village included Middle Disaster Resilient Village with the interaction SO is fulfillment sister village program requirements, the results of WO are disaster simulations be activated and need a balanced allocation, the result of ST is readiness in various aspects that can minimize disaster risk and the result of WT is balancing prevention services.
\end{abstract}

Keywords: Sister Village, Disaster Resilient Village

\begin{abstract}
Abstrak
Desa Pusung secara morfologi terletak didaerah Kaki Gunung Api Merapi. Berdasarkan Peta Kawasan Rawan Bencana (KRB) Letusan Gunung Merapi tahun 2010, Desa Pusung termasuk dalam KRB I. Pasca letusan 2010, Desa Pusung mulai dikembangkan program mitigasi bencana sister village sebagai tempat pengungsian. Namun dalam pelaksanaannya, program mitigasi bencana tersebut dengan segenap aspek ketangguhan desa terhadap bencana belum berjalan optimal. Maka, penelitian ini dilakukan untuk mengetahui tingkat ketangguhan Desa Pusung dan arahan pelaksanaan ketangguhan desa terhadap bencana letusan Gunung Merapi. Metode yang digunakan adalah penskoran dan SWOT terhadap hasil kuisioner dan observasi desa tangguh bencana. Hasil penelitian ini adalah Desa Pusung termasuk dalam Desa Tangguh Bencana Madya dengan hasil interaksi SO adalah terpenuhinya persyaratan program sister village, hasil interaksi WO adalah simulasi bencana perlu diaktifkan dan perlu alokasi dana yang seimbang, hasil interaksi ST adalah kesiapan diberbagai aspek yang dapat memperkecil risiko bencana dan hasil interaksi WT adalah penyeimbangan pelayanan penanggulangan.
\end{abstract}

Kata kunci: Sister Village, Desa Tangguh Bencana

Social, Humanities, and Education Studies (SHEs): Conference Series https://jurnal.uns.ac.id/shes 


\section{PENDAHULUAN}

Desa Pusung yang berada di Kecamatan Boyolali, Kabupaten Boyolali secara gemorfologi terletak didaerah Kaki Gunung Api Merapi atau menurut Van Bemmelen diklasifikasikan kedalam bentuklahan V7. Berdasarkan Peta Kawasan Rawan Bencana (KRB) Letusan Gunung Merapi tahun 2010, Desa Pusung termasuk dalam KRB I dalam radius $20 \mathrm{~km}$ dari timur kawah. Pada letusan Gunung Merapi tahun 2010, Desa Pusung juga terdampak hujan abu yang cukup tebal dan terjadi banjir lahar dingin terusan di anak sungai/ Kali Pepe yang melewati sebelah selatan desa. Aktivitas letusan Gunung Merapi tahun 2010 silam tergolong erupsi yang terbesar jika dibandingkan dengan erupsi dalam kurun waktu beberapa dekade terakhir (Marliyani, 2010). Dimana total 347 korban jiwa melayang akibat bencana ini (BNPB, 2010). Hal tersebut dapat mengindikasikan bahwa masih kurangnya kesiapsiagaan masyarakat beserta pemerintah dalam menghadapi bencana letusan Gunung Merapi. Akan tetapi bagaimanapun dahsatnya letusan, penghidupan masyarakat setempat akan tetap berlanjut dengan hidup berdampingan dengan bencana atau diistilahkan living with risk (Smith dan Petley, 2009).

Pasca letusan 2010 silam, desa-desa yang berada di Kecamatan Boyolali mulai dikembangkan program mitigasi bencana bernama desa bersaudara atau sister village atau paseduluran ndeso (Astriani, 2017). Mitigasi tersebut merupakan bentuk kerjasama dalam konteks krisis bencana letusan Gunung Merapi, dimana desa terdampak yang berada di KRB I dan KRB II dapat dibantu oleh desa yang dinilai cukup aman sebagai penyedia tempat pengungsian dan membantu dalam proses evakuasi (Estuning Tyas Wulan Mei. dkk, 2018). Dalam pelaksanaannya, program sister village perlu ditunjang oleh peran aktif serta kerjasama antara masyarakat desa terdampak dan masyarakat desa penerima. Sebab masyarakat merupakan elemen yang memiliki pengalaman langsung dalam kejadian bencana sehingga pemahaman yang dimiliki menjadi modal bagi pengurangan risiko bencana. Desa yang terdampak letusan Gunung Merapi di Kabupaten Boyolali teragihkan di Kecamatan Selo, Kecamatan Cepogo dan Kecamatan Musuk. Adapun desa penerimanya yang tersebar di Kecamatan Boyolali (diantaranya Desa Pusung) dan satu desa yang berada di Kecamatan Mojosongo. Namun dalam pelaksanaannya, program mitigasi bencana tersebut dengan segenap aspek ketangguhan Desa Pusung terhadap bencana letusan Gunung Merapi belum berjalan dengan baik dan optimal. Seperti masih rendahnya kesadaran masyarakat terhadap simulasi bencana, belum adanya anggaran dana desa yang seimbang untuk kegiatan mitigasi bencana dan kurangnya pengorganisasian masyarakat untuk melaksanakan program sister village. Mengingat program sister village dapat menjadi salah satu motor penggerak sistem sosial dalam aspek ketangguhan desa terhadap bencana. Dimana sistem sosial mampu mengorganisir dirinya sendiri (organizing itself) untuk meningkatkan kapasitas belajar dari bencana masa lalu untuk perlindungan masa depan yang lebih baik dan untuk meningkatkan langkah-langkah pengurangan risiko (Yasin Yusup, 2014). Maka dengan sistem sosial yang terbentuk dapat mencapai aspek ketangguhan desa yang meliputi: legislasi, perencanaan, kelembagaan, pendanaan, pengembangan kapasitas dan penyelenggaraan penanggulangan bencana (BNPB, 2012). Berdasarkan latar belakang masalah tersebut, penelitian ini dilakukan untuk mengetahui tingkat ketangguhan Desa Pusung terhadap letusan Gunung Merapi dan untuk mengetahui arahan pelaksanaan ketangguhan Desa Pusung terhadap bencana letusan Gunung Merapi. Sehingga dapat membentuk masyarakat yang mampu beradaptasi terhadap perubahan alam dalam jangka waktu yang lama atau berkelanjutan (Armijos, M.T, et al. 2017), dengan menerapkan sistem penanganan bencana yang tepat untuk mengurangi risiko bencana letusan Gunung Merapi. 


\section{METODE}

Metode yang digunakan dalam penelitian ini adalah penelitian deskriptif kualitatif. Tujuan pertama penelitian ini mengetahui tingkat ketangguhan Desa Pusung terhadap letusan Gunung Merapi, sumber data yang digunakan adalah kuisioner Desa Tangguh Bencana berdasarkan Peraturan Kepala BNPB Nomor. 1 Tahun 2012 tentang pedoman Umum Desa/ Kelurahan Tangguh Bencana, dimana kuisioner ini ditujukan kepada Kepala Desa Pusung. Teknik analisis data yang digunakan adalah penskoran kuisioner ketangguhan Desa Pusung terhadap bencana letusan Gunung Merapi.

Tabel 1. Klasifikasi Desa Tangguh Bencana

\begin{tabular}{|c|c|}
\hline Klasifikasi Desa Tangguh Bencana & Skor \\
\hline Utama & $51-60$ \\
\hline Madya & $36-50$ \\
\hline Pratama & $20-35$ \\
\hline
\end{tabular}

Sumber: BNPB, 2012

Selain itu, tujuan penelitian yang ke-dua adalah untuk mengetahui arahan pelaksanaan ketangguhan Desa Pusung terhadap bencana letusan Gunung Merapi, sumber data yang digunakan adalah kuisioner Desa Tangguh Bencana yang memuat aspek-aspek ketangguhan desa dan observasi lapangan terkait aspek ketangguhan Desa Pusung terhadap bencana letusan Gunung Merapi. Teknik analisis data yang digunakan adalah teknik analisis SWOT oleh Lutfi Muta'ali dengan mengidentifikasi SWOT kemudian membandingkannya kedalam elemen internal dan eksternal daerah kajian. Analisis ini ditujukan untuk mengetahui kekuatan, kelemahan, kesempatan dan ancaman atau dari analisis bencana mengenai letusan Gunung Merapi. Selain itu, analisis ini ditujukan untuk mengetahui interaksi SWOT sebagai penentu arahan pelaksanaan ketangguhan Desa Pusung terhadap bencana letusan Gunung Merapi.

\section{HASIL DAN PEMBAHASAN}

\section{Tingkat Ketangguhan Desa Pusung terhadap Bencana Letusan Gunung Merapi}

Berdasarkan kuesioner desa tangguh bencana di Desa Pusung yang terdiri dari 60 butir pertanyaan dan memuat 6 aspek desa tangguh bencana, dapat diketahui bahwa total hasil penskoran kuisioner desa tangguh bencana di Desa Pusung adalah 48 skor. Berikut ini diagram aspek desa tangguh bencana di Desa Pusung berdasarkan hasil kuisioner yang telah diperoleh.

\section{Gambar 1. Diagram Aspek Desa Tangguh Bencana Letusan Merapi di Desa Pusung}

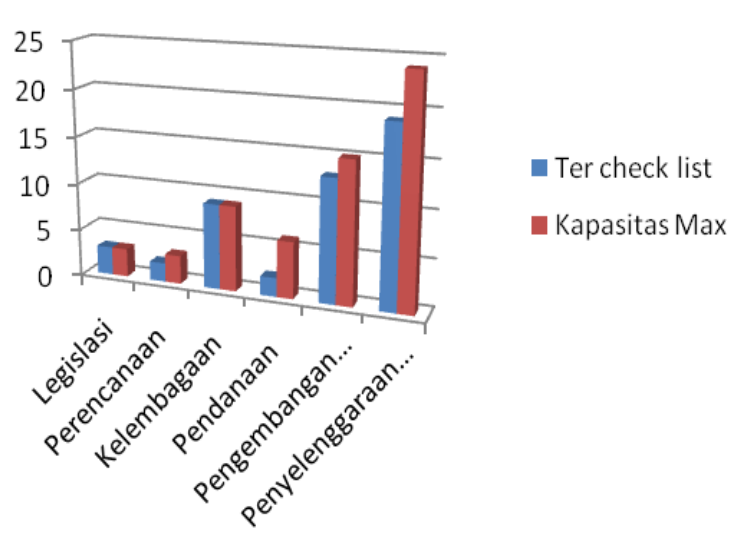


Hal tersebut mengindikasikan bahwa Desa Pusung termasuk dalam klasifikasi Desa Tangguh Bencana tingkat Madya terhadap bencana letusan Gunung Merapi. Atas dasar tingkat ketangguhan desa tersebut, maka dapat diketahui kriteria Desa Pusung sebagai desa tangguh bencana berikut: (1) adanya kebijakan Pengurangan Risiko Bencana (PRB) yang tengah dikembangkan di tingkat desa; (2) adanya dokumen perencanaan Penanggulangan Bencana (PB) yang telah tersusun tetapi belum terpadu ke dalam instrumen perencanaan desa; (3) adanya forum Pengurangan Risiko Bencana yang beranggotakan wakil-wakil dari masyarakat, termasuk kelompok perempuan dan kelompok rentan, tetapi belum berfungsi penuh dan aktif; (4) adanya tim relawan Penanggulangan Bencana desa yang terlibat dalam kegiatan peningkatan kapasitas, pengetahuan dan pendidikan kebencanaan bagi para anggotanya dan masyarakat pada umumnya, tetapi belum rutin dan tidak terlalu aktif; (5) adanya upaya-upaya untuk mengadakan pengkajian risiko, manajemen risiko dan pengurangan kerentanan, termasuk kegiatan-kegiatan ekonomi produktif alternatif untuk mengurangi kerentanan, tetapi belum terlalu teruji; dan (6) adanya upaya-upaya untuk meningkatkan kapasitas kesiapsiagaan serta tanggap bencana yang belum teruji dan sistematis.

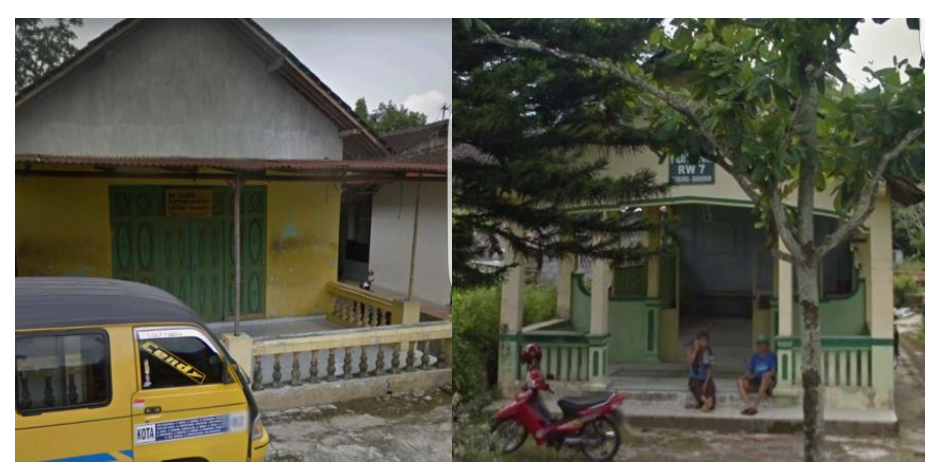

Gambar 2. Aula dan Balai Desa Pusung sebagai Tempat Pengungsian Letusan Gunung Merapi

Sumber: Dokumentasi Penulis, 2020

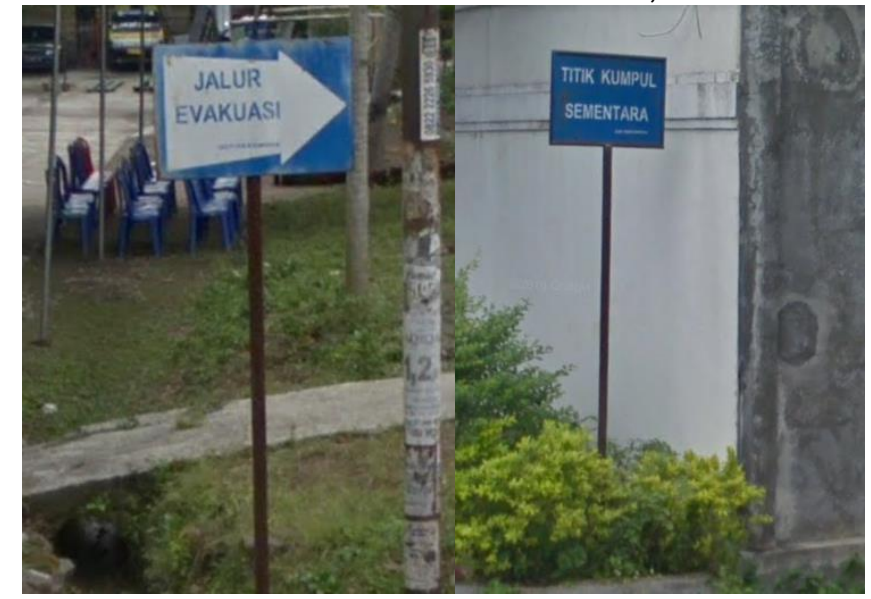

Gambar 3. Jalur Evakuasi dan Titik Kumpul Sementara di Desa Pusung Sumber: Dokumentasi Penulis, 2020 


\section{Arahan Pelaksanaan Ketangguhan Desa Pusung terhadap Bencana Letusan Gunung Merapi}

Untuk menentukan arahan pelaksanaan ketangguhan Desa Pusung terhadap letusan Gunung Merapi. Maka diperlukan identifikasi SWOT (Strengthss, Weaknesses, Opportunities, Threats) terhadap aspek ketangguhan Desa Pusung dalam menghadapi bencana Letusan Gunung Merapi melalui daftar aspek ketangguhan desa yang tertera pada kuisioner dan observasi lapangan sebagai berikut:

\section{Tabel 2. Identifikasi SWOT Aspek Ketangguhan Desa Pusung}

\begin{tabular}{|c|c|}
\hline S (Strengths) & W (Weaknesses) \\
\hline $\begin{array}{l}\text { 1. Adanya forum pengurangan risiko } \\
\text { bencana dan simulasi secara berkala } \\
\text { oleh tim relawan tingkat kelurahan } \\
\text { (Aspek Kelembagaan) }\end{array}$ & $\begin{array}{l}\text { 1. Belum terpadunya dokumen } \\
\text { penanggulangan bencana dengan } \\
\text { instrumen perencanaan desa (Aspek } \\
\text { Perencanaan) }\end{array}$ \\
\hline $\begin{array}{l}\text { 2. Adanya anggaran untuk } \\
\text { pembangunan fisik pengurangan } \\
\text { risiko bencana (Aspek Pendanaan) }\end{array}$ & $\begin{array}{l}\text { 2. Belum optimalnya alokasi dana } \\
\text { khusus desa untuk kegiatan tanggap } \\
\text { darurat bencana (Aspek Pendanaan) }\end{array}$ \\
\hline $\begin{array}{l}\text { 3. Adanya sosialisasi kebencanaan, } \\
\text { terdapat kelompok masyarakat } \\
\text { relawan bencana dan terdapat } \\
\text { pembangunan sistem peringatan dini } \\
\text { (Aspek Kapasitas Pengembangan) }\end{array}$ & $\begin{array}{l}\text { 3. Minimnya jumlah relawan bencana } \\
\text { yang aktif dan kelompok perempuan } \\
\text { masih minim baik jumlah dan } \\
\text { keaktifannya (Aspek Kapasitas } \\
\text { Pengembangan) }\end{array}$ \\
\hline $\begin{array}{l}\text { 4. Adanya analisis risiko bencana, } \\
\text { adanya pengembangan ekonomi } \\
\text { untuk mengurangi kerentanan, } \\
\text { adanya program perlindungan } \\
\text { kesehatan kelompok rentan (Aspek } \\
\text { Penyelenggaraan Penanggulangan) }\end{array}$ & $\begin{array}{l}\text { 4. Rendahnya minat masyarakat dalam } \\
\text { simulasi bencana, belum adanya } \\
\text { pengelolaan sumberdaya } \\
\text { pengurangan risiko bencana, belum } \\
\text { adanya kegiatan yang jelas untuk } \\
\text { melindungi aset-aset produktif } \\
\text { masyarakat (Aspek Penyelenggaraan } \\
\text { Penanggulangan) }\end{array}$ \\
\hline O (Opportunities) & \\
\hline $\begin{array}{l}\text { Desa Pusung dapat berkembang } \\
\text { menjadi Desa Tangguh Bencana Tingkat } \\
\text { Utama, karena adanya rujukan } \\
\text { penyelenggaraan program sister village } \\
\text { (tempat pengungsian) oleh BPBD } \\
\text { Kabupaten Boyolali sebagai penggerak } \\
\text { kegiatan mitigasi bencana. }\end{array}$ & $\begin{array}{l}\text { 1. Ancaman sebagai daerah terdampak } \\
\text { letusan Merapi dengan skala letusan } \\
\text { yang kuat } \\
\text { 2. Perlunya koordinasi dengan desa } \\
\text { program sister village lainnya dan } \\
\text { BPBD untuk menilai ketersediaan } \\
\text { antara alokasi jumlah pengungsi } \\
\text { dengan kapasitas pengungsian }\end{array}$ \\
\hline
\end{tabular}

Sumber: Hasil Observasi Aspek Ketangguhan Desa Pusung, 2020

Setelah mengidentifikasi SWOT aspek ketangguhan Desa Pusung terhadap letusan Gunung Merapi, maka dapat melakukan penentuan arahan pelaksanaan ketangguhan Desa Pusung terhadap letusan Gunung Merapi dengan menggolongkan terlebih dahulu hasil SWOT kedalam interaksi faktor internal yang terdiri dari strenghts $(S)$, weaknesses $(W)$ dan faktor eksternal yang terdiri dari opportunities $(O)$, threats $(T)$. Faktor internal dan faktor eksternal dapat dicari interaksi strenghts dan opportunities (SO), strenghts dan threats (ST), weaknesses dan opportunities (WO), 
serta weaknesses dan threats (WT) untuk menghasilkan arahan pelaksanaan ketangguhan desa sebagai berikut:

Tabel 3. Matriks Interaksi Faktor Eksternal dan Internal Desa Tangguh Bencana di Desa Pusung

\begin{tabular}{|c|c|c|}
\hline $\begin{array}{l}\text { F. } \\
\text { Eks }\end{array}$ & S (Strengths) & W (Weaknesses) \\
\hline $\begin{array}{c}0 \\
\text { (Opportunities) }\end{array}$ & $\begin{array}{l}\text { Desa Pusung dapat } \\
\text { memenuhi persyaratan } \\
\text { program sister village karena } \\
\text { adanya kesiapan fisik dan } \\
\text { sosial desa. } \\
\text { Sehingga program tersebut } \\
\text { dapat dioptimalkan untuk } \\
\text { mendukung ketangguhan } \\
\text { desa terhadap bencana } \\
\text { letusan Gunung Merapi. }\end{array}$ & $\begin{array}{l}\text { Adanya hambatan keberjalanan } \\
\text { program sister village yang } \\
\text { disebabkan minimnya simulasi } \\
\text { bencana secara aktif dan berkala } \\
\text { serta alokasi dana yang belum } \\
\text { seimbang. } \\
\text { Sehingga diperlukan peningkatan } \\
\text { keaktifan masyarakat dalam } \\
\text { simulasi bencana dan perbaikan } \\
\text { alokasi dana desa yang seimbang } \\
\text { untuk mendukung pelaksanaan } \\
\text { mitigasi bencana. }\end{array}$ \\
\hline T (Threats) & 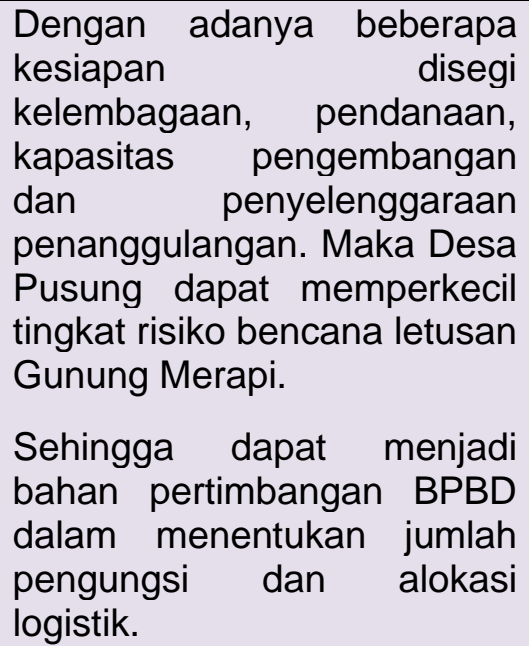 & $\begin{array}{l}\text { Pelayanan desa terhadap } \\
\text { penanggulangan bencana tidak } \\
\text { berjalan secara optimal karena } \\
\text { adanya ketidakseimbangan jumlah } \\
\text { tim relawan dengan jumlah } \\
\text { pengungsi dan adanya } \\
\text { kecemburuan sosial warga } \\
\text { setempat terkait alokasi bantuan. } \\
\text { Sehingga perlu penyeimbangan } \\
\text { pelayanan, kapasitas pengungsian } \\
\text { dan peningkatan pemahaman } \\
\text { masyarakat setempat. }\end{array}$ \\
\hline
\end{tabular}

Sumber: Analisis Penulis, 2020

Berdasarkan interaksi faktor internal dan faktor ekternal SWOT Desa Pusung sebagai Desa Tangguh Bencana tingkat Madya. Maka dapat diketahui arahan pelaksanaan ketangguhan Desa Pusung sebagai desa tangguh bencana terhadap bencana letusan Gunung Merapi. Arahan yang pertama adalah program sister village perlu dioptimalkan untuk mendukung dan menggerakan ketangguhan Desa Pusung terhadap bencana letusan Gunung Merapi, kemudian diperlukan keaktifan masyarakat Desa Pusung dalam simulasi bencana yang diimbangi dengan alokasi dana yang baik untuk mendukung pelaksanaan simulasi dan program sister village. Arahan yang selanjutnya adalah BPBD dapat mempertimbangkan dan menentukan jumlah pengungsi serta alokasi logistik dengan kapasitas desa, dan diperlukan penyeimbangan pelayanan, kapasitas pengungsian serta pemahaman masyarakat setempat. 


\section{SIMPULAN}

Desa Pusung termasuk dalam Desa Tangguh Bencana Tingkat Madya dengan total skor 48. Adapun identifikasi SWOT ketangguhan Desa Pusung terhadap bencana letusan Merapi, yakni (strengths) adanya forum PRB, anggaran pembangunan fisik, sosialisasi kebencanaan dan analisis risiko; (weaknesses) belum terpadunya dokumen penanggulangan bencana, belum optimalnya alokasi dana, jumlah relawan minim dan rendahnya minat masyarakat; (opportunities) adanya rujukan penyelenggaraan sister village oleh BPBD; (threats) adanya ancaman wilayah terdampak akibat letusan yang kuat dan perlunya koordinasi terkait kapasitas pengungsian. Arahan pelaksanaan ketangguhan Desa Pusung terhadap bencana letusan Gunung Merapi dapat diketahui bahwa: (1) terpenuhinya persyaratan program sister village dan perlu dioptimalkan untuk menggerakan program mitigasi lainnya; (2) perlu peningkatan keaktifan masyarakat dalam simulasi bencana dan perbaikan alokasi dana desa yang seimbang untuk mendukung pelaksanaan mitigasi bencana; (3) perlu pertimbangan oleh BPBD dalam menentukan jumlah pengungsi dan alokasi logistik; dan (4) perlu penyeimbangan pelayanan, kapasitas pengungsian dan peningkatan pemahaman masyarakat setempat.

Dengan adanya hasil penelitian ini, dapat dijadikan dasar pelaksanaan pengurangan risiko bencana oleh Desa Pusung terhadap letusan Gunung Merapi, dengan melaksanakan program sister village sebagai penggerak masyarakat dalam melaksanakan mitigasi bencana letusan Gunung Merapi. Keberlangsungan ketangguhan desa ini dapat menjadi kajian penelitian selanjutnya mengenai analisis keluarga tangguh bencana letusan Gunung Merapi.

\section{DAFTAR PUSTAKA}

Armijos, M. T., dkk. (2017). Adapting to Change in Volcanic Behaviour: Formal and Informal Interactions for Enhanced Risk Management at Tungurahua Volcano, Ecuador. Global Environmental Change. 45 (201): 217.

Astriani, F. (2017). Mitigasi Bencana Gunung Merapi Berbasis Desa Bersaudara (Sister Village) di Kecamatan Musuk Kabupaten Boyolali Jawa Tengah. Skripsi. Universitas Muhammadiyah Surakarta.

Badan Geologi. Peta Kawasan Rawan Bencana Gunung Merapi dan Area Terdampak Letusan 2010. Jakarta: Kementrian Energi dan Sumber Daya Mineral.

BNPB. (2012). Peraturan Kepala Badan Nasional Penanggulangan Bencana Nomor 1 Tahun 2012 Tentang Pedoman Umum Desal Kelurahan Tangguh Bencana. Jakarta: Penulis.

Geospasial, BNPB. (2020 Agustus 8). Peta Rekapitulasi Per Kabupaten Jumlah Korban, Pengungsi dan Kerusakan Akibat Letusan Gunung Merapi 30 November 2010. Diakses dari http://geospasial.bnpb.go.id.

Hermon, D. (2015). Geografi Bencana Alam. Jakarta: PT Raja Grafindo Persada.

Marliyani, G. I. (2010). An Overfiew of Merapi Volcano, Central Java, Indonesia. Gadjah Mada University-San Diego State University, USA.

Mei, E. T. W., dkk. (2018). Sister Village: Strategi Alternatif Mitigasi Bencana Gunung Api. Yogyakarta: Gadjah Mada University Press.

Muta'ali, L. (2015). Teknik Analisis Regional untuk Perencanaan Wilayah, Tata Ruang dan Lingkungan. Badan Penelitian Fakultas Geografi UGM. Yogyakarta.

Rozi, S. (2016). Memahami Erupsi Merapi; Kebijakan dan Implementasi. Yogyakarta: Graha IImu.

Smith, K., and Petley, D. N. (2009) Environmental Hazards: Assessing Risk and Reducing Disaster. Fifth Edition. Routledge.

Yusup, Y. (2014). Hidup Bersama Risiko Bencana: Konstruksi Ruang dalam Perspektif Ruang Relasional. Jurnal Perencanaan Wilayah dan Kota. 25 (1): 59. 